\title{
Perennial and seasonal contamination of maize by aflatoxins in eastern Kenya
}

\author{
Meshack Amos Obonyo* and Elsie Nyangweso Salano
}

\begin{abstract}
Background: Aflatoxin contamination of grain is a major constraint to sustained quality cereal production. The causative fungi, Aspergillus species infect crops in the field and continue to do so post-harvest where they produce toxins in store. The current study aimed at establishing seasonal variation in levels and types of aflatoxins in maize from the Eastern region of Kenya- the hot-spot for aflatoxicosis. Maize kernels were collected from farmers' households in May and December 2013 -2 months after long rain and short rain season respectively. The total aflatoxins were quantified using Enzyme-Linked Immunosorbent Assay (ELISA), while the toxin composition was determined using Thin-Layer Chromatography (TLC) and confirmed using High-Performance Liquid Chromatography (HPLC).

Results: Generally, grain harvested after the long rains (May) had significantly $(p=0.019)$ lower aflatoxin levels and variation $\left(5.68 \pm 6.31 \mathrm{ppb}, 100 \%\right.$ Aflatoxin B1) than that of short rains $\left(10.77 \pm 10.14 \mathrm{ppb}, 72 \% \mathrm{AFB}_{1}\right)$. Additionally, from the long and short rain seasons, the samples exceeding regulatory allowed limit (10 ppb) were 16 and $44 \%$ respectively.

Conclusion: In Eastern Kenya, consumption of maize harvested in the long rain season presents a recurrent risk of exposure to low levels of $\mathrm{AFB}_{1}$; while consumption of maize harvested after the short rain season presents a risk of seasonal exposure to high levels and mixed type of toxins However, this long term risk of exposure to aflatoxins is poorly documented hence these findings necessitate mitigation measures because $\mathrm{AFB}_{1}-$ is a potent class 1 mutagenic toxin likely to cause liver cancer.
\end{abstract}

Keywords: Aspergillus, Risks, Aflatoxicosis, Maize, Seasonality

\section{Background}

Over the last four decades, Kenya has become one of the leading countries in terms of incidence and severity of human exposure to aflatoxins (Mehl and Cotty 2010). The most severe episode in 2004 had 317 reported cases of which 125 were fatal (Probst et al. 2007). It is believed that the magnitude of exposure could be higher than reported for lack of robust monitoring systems. Consumption of aflatoxin contaminated grain has adverse health implications such as abdominal distensions, immune suppression (Cusumano et al. 1996), cancer, stunted growth in children (Gong et al. 2004) including death at high level of exposure (Probst et al. 2011). The majority of the fatalities reported in Kenya have occurred in the lower Eastern region of the country, which lead to a

\footnotetext{
* Correspondence: obonyom@gmail.com; meshack.obonyo@egerton.ac.ke Department of Biochemistry and Molecular Biology, Egerton University, P. O. Box 536-20115, Egerton, Kenya
}

widely accepted view that the region is the hot-spot of aflatoxicosis.

The factors underlying repeated aflatoxicosis episodes in the hot-spot area of Kenya are yet to be unravelled. However, previous studies attribute high residual mycotoxin levels to climatic changes while others link it to ongoing anthropogenic causes such as delayed harvesting, poor drying and storage conditions (Torres et al. 2014). Among the important climatic factors are rainfall and temperature which affect residual grain moisture content and density of the aflatoxigenic fungi (Cotty and Jaime-Garcia 2007; Milani 2013). There is evidence showing a positive correlation between aflatoxins level and climatic seasons. This has been documented in in Nepal where aflatoxins were higher in crops harvested during the dry season (Gautam et al. 2008) while in Sierra Leone, human exposure to aflatoxins and ochratoxins appeared higher in the dry season than the rainy one suggesting higher contamination (Jonsyn-Ellis 2001). 
The mentioned studies support the hypothesis that aflatoxicosis is largely seasonal with an opportunity for prediction hence mitigation. Therefore, it's imperative to determine the nature of risk in the hot-spot region for appropriate intervention. The current study sought to achieve two objectives (i) establish the variation of aflatoxins in maize by cropping season and (ii) determine the predominant type of toxin in each respective season. To the best of our knowledge, this information is lacking hence hampering long-term management efforts in the hot-spot region of Eastern Kenya.

\section{Methods}

\section{Sample collection}

The study site (Eastern Kenya) is semi-arid with an annual conditions as follows: rainfall $250-500 \mathrm{~mm}$, RH $60-70 \%$ and temperature $23-34{ }^{\circ} \mathrm{C}$ (Freeman and Coe 2002). Samples were collected in May and December 2013 approximately 2 months after harvest following the long and short rain season of the year. An altitudinal transect Machakos $1^{\circ} 31^{\prime} 0.0120^{\prime \prime}$ S37 ${ }^{\circ} 16^{\prime} 0.0120^{\prime \prime} \mathrm{E}$ [1000-1600 masl] to Kitui $1^{\circ} 22^{\prime} 1.0560^{\prime \prime} \mathrm{S} 38^{\circ} 0^{\prime}$ $37.9800^{\prime \prime}$ E [400-1163 masl]) was selected from which sampling points were set every $5 \mathrm{~km}$ in the $100 \mathrm{Km}$ road. At each sampling, farmers on both sides of the main road were randomly selected. A sample consisted of half a kilogram of shelled maize Kernels that was being used for immediate consumption. Samples were separately kept in brown Khaki bags, labelled and transported in a cool box to the laboratory, stored at $4{ }^{\circ} \mathrm{C}$ until analysis. During the second season, repeated sampling was undertaken in the same areas. In total, about 200 samples were collected in both seasons but were segregated depending on whether the farmer had harvested the maize from their farm or purchased during either of the seasons. All samples from farmers who had purchased maize were excluded from the current results. Due to poor harvest experienced during in 2013, most farmers had purchased maize for their daily use. Thus, only a total of 50 maize samples from both seasons were analysed further.

\section{Quantification of total aflatoxins}

Maize Kernels were ground to fine powder using a mill grinder. To $20 \mathrm{~g}$ of the maize powder, $100 \mathrm{ml}$ of extraction solvent ( $70 \%$ methanol) was added in a conical flask. The flask was covered with aluminium foil and vortexed for $2 \mathrm{~min}$. The mixture was then allowed to settle then filtered (Whatman \# 1). $10 \mathrm{ml}$ of the filtrate was drawn for aflatoxin testing using a solid phase direct competitive Enzyme-Linked Immunosorbent Assay, following manufacturer's instruction (HELICA Biosystems Inc). The absorbance was read at $450 \mathrm{~nm}$ in a microplate reader (ThermoScientific). A standard curve was generated using the absorbance and the known concentrations of the six standards (HELICA Biosystems Inc). The concentrations of the samples were interpolated from the standard curve using GraphPad Prism version 6.0.5.0.

\section{Identification of aflatoxin types}

Standard procedure for performing and analysis of aflatoxins by TLC were followed as described by Jager et al. (2013). Briefly, $20 \mathrm{~g}$ of maize powder was added to a $500 \mathrm{ml}$ flat-bottomed flask. Into it, a mixture of $25 \mathrm{~g}$ hyflosupercel, $200 \mathrm{ml}$ chloroform, and $20 \mathrm{ml}$ distilled water was added then covered and shaken on a mechanical shaker for $30 \mathrm{~min}$. After filtration (Whatman \# 1) the first $100 \mathrm{ml}$ was collected and concentrated. Two-thirds of a column chromatography tube was filled with chloroform after which $5 \mathrm{~g}$ of $\mathrm{Na}_{2} \mathrm{SO}_{4}$ was added. $10 \mathrm{~g}$ of silica gel slurry was transferred into the column and the setup allowed to stand for $15 \mathrm{~min}$ and $15 \mathrm{~g}$ of $\mathrm{Na}_{2} \mathrm{SO}_{4}$. The chloroform was drained and extract was transferred into the silica gel column. Hexane $(100 \mathrm{ml})$ was added then drained followed by $100 \mathrm{ml}$ of diethyl. Alfatoxins were eluted using $100 \mathrm{ml}$ of a chloroform-methanol mixture (ratio 145.5:4.5) and collected into a round-bottomed flask for examination under UV light at $360 \mathrm{~nm}$ while compared to the standards. Afterwards, the positive samples were taken for further HPLC analysis in order to confirm the identity of the individual toxins, at the National Public Health Research Laboratories.

\section{Data analysis}

Prior to analysis, the "equality of variances" test was used to inform the choice of T-test procedure. The test revealed insufficient evidence of unequal variances (the Folded F statistic $F^{\prime}=2.58$, with $p=0.0240$ ) between the two seasons. Hence, a pooled T-test was used for comparison of the total aflatoxins in maize samples drawn from the long and short rainfall seasons. The data was analysed using R Software version (3.3.1). In addition to comparison of the seasons, the number of samples unfit for human consumption (above $10 \mathrm{ppb}$ ) as well as prevalence of the different aflatoxins was also determined.

\section{Results}

\section{Quantification of total aflatoxins}

In general, maize from the long rain season had significantly $(p=0.0191)$ lower (mean $\pm \mathrm{SD})$ aflatoxin levels $(5.68 \pm 6.31 \mathrm{ppb})$ than those from the short rain season (10.77 $\pm 10.14 \mathrm{ppb})$ (Table 1).

Additionally, samples unsuitable for human consumption (aflatoxin >10 ppb) were 16\% (long season) and $25 \%$ (short season) respectively. 
Table 1 Summary T-test statistics for comparison of the long and short rain season

\begin{tabular}{lclll}
\hline Season & Sample(n) & Mean aflatoxin & Std Dev & Std Err \\
\hline Long Rain & 25 & 5.68 & 6.31 & 1.26 \\
Short Rain & 25 & 10.77 & 10.14 & 2.03 \\
Diff $(1-2)$ & & -5.09 & 8.45 & 2.39
\end{tabular}

Means obtained after equality of variance and pooled T-test (DF, $48, t$ value $-2.13, p=0.0191)$

\section{Identification of aflatoxin types}

Four types of aflatoxins $\left(B_{1}, B_{2}, G_{1}\right.$ and $\left.G_{2}\right)$ were reported with $\mathrm{AFB}_{1}$ in $100 \%$ of samples in the long rain season while the short season were mixed aflatoxins. In the short rains season, the levels of toxins in decreasing order were: $\mathrm{AFB}_{1} 72 \%, \mathrm{AFG}_{1} 28 \%, \mathrm{AFB}_{2} 8 \%$, and the least was $\mathrm{AFG}_{2} 4 \%$. Additionally, there were $12 \%$ of the samples with $\mathrm{AFB}_{1}$ and $\mathrm{AFG}_{1}$ appearing as mixed contamination (Table 2).

\section{Discussion}

Aflatoxin contamination of grain is an impediment to quality food production and trade across the globe (Kebede et al. 2012). In Kenya, it's a life-threatening phenomenon because aflatoxicosis occurs with concomitant human fatalities. The current study was designed to explain the observed high levels of aflatoxins in the region by separating contamination of grain that is due to grain importation into the hot-spot region from that which is due to local production. The findings show that from $25 \%$ of grain consumed in 2013 in the sampled region, there is a twofold increase in aflatoxins recorded in maize consumed during the short rain season compared to the long rain season. Recently, in western Kenya-a major maize and peanut producing region of the country, the incidence of three maize ear rots (Fusarium, Penicillium, and Aspergillus) and their corresponding toxins were severe during the long rain season than the

Table 2 Seasonal variation of total aflatoxins (ppb) and toxin type in maize harvested after the long and short rain cropping season

\begin{tabular}{|c|c|c|c|c|c|}
\hline \multicolumn{3}{|c|}{ Long cropping season (Season 1) $n=25$} & \multicolumn{3}{|c|}{ Short cropping season (Season 2) $n=25$} \\
\hline Sample Code & Total Toxins (ppb) & Toxin Type & Sample Code & Total Toxins (ppb) & Toxin Type \\
\hline $1 \mathrm{EM} 14$ & 3.6 & B1 & 2EM02 & 30.0 & $\mathrm{B1}, \mathrm{G} 1$ \\
\hline 1 EM15 & 3.6 & B1 & 2EM03 & 1.4 & B1 \\
\hline $1 \mathrm{EM} 18$ & 3.0 & B1 & 2EM04 & 8.0 & B1 \\
\hline $1 \mathrm{EM} 19$ & 3.1 & B1 & 2EM05 & 2.5 & B1 \\
\hline $1 \mathrm{EM} 20$ & 6.0 & B1 & 2EM06 & 12.7 & B1 \\
\hline $1 \mathrm{EM} 21$ & 2.2 & B1 & 2EM07 & 15.4 & B2 \\
\hline $1 \mathrm{EM} 23$ & 2.2 & B1 & 2EM09 & 2.7 & G1 \\
\hline $1 \mathrm{EM} 24$ & 21.3 & B1 & 2EM11 & 2.2 & B1 \\
\hline 1EM25 & 2.2 & B1 & 2EM12 & 15.2 & B2 \\
\hline $1 \mathrm{EM} 26$ & 13.3 & B1 & 2EM22 & 1.2 & B1 \\
\hline $1 \mathrm{EM} 27$ & 4.5 & B1 & 2EM30 & 3.2 & B1 \\
\hline 1EM28 & 2.4 & B1 & 2EM34 & 2.9 & $\mathrm{~B} 1, \mathrm{G} 1$ \\
\hline $1 \mathrm{EM} 29$ & 1.2 & B1 & 2EM35 & 24.3 & G1 \\
\hline 1 EM30 & 4.0 & B1 & 2EM42 & 2.0 & B1 \\
\hline $1 \mathrm{EM} 32$ & 3.5 & B1 & 2EM43 & 1.5 & B1 \\
\hline $1 \mathrm{EM} 33$ & 18.4 & B1 & 2EM51 & 1.6 & B1 \\
\hline 1EM35 & 1.9 & B1 & 2EM52 & 3.2 & B1 \\
\hline $1 \mathrm{EM} 36$ & 5.1 & B1 & 2EM54 & 19.2 & B1 \\
\hline $1 \mathrm{EM} 41$ & 2.6 & B1 & 2EM55 & 10.0 & G1 \\
\hline $1 \mathrm{EM} 42$ & 23.7 & B1 & 2EM61 & 2.6 & B1 \\
\hline 1EM45 & 2.8 & B1 & 2EM63 & 27.0 & G1 \\
\hline $1 \mathrm{EM} 46$ & 4.3 & B1 & 2EM66 & 19.8 & B1 \\
\hline $1 \mathrm{EM} 47$ & 3.0 & B1 & 2EM86 & 25.6 & $\mathrm{~B} 1, \mathrm{G} 1$ \\
\hline 1EM48 & 2.8 & B1 & 2EM87 & 28.9 & G2 \\
\hline $1 \mathrm{EM} 49$ & 1.3 & B1 & 2EM92 & 6.2 & B1 \\
\hline Mean \pm SD & $5.68 \pm 6.31$ & & & $10.77 \pm 10.14$ & \\
\hline
\end{tabular}


short one (Juti 2017). While the recent findings could be explained by the climatic differences between the two agro-ecological zones (Mugo et al. 2016), the studies attest to seasonal variation in level toxins in food material.

The current findings form an important basis for planning intervention against dietary exposure to aflatoxins since the rainfall pattern in major parts of the country is bimodal characterised by long and short rainy seasons interspersed with brief dry spells (Mugo et al. 2016). A seasonal assessment of aflatoxin residues in food is an important indicator of aflatoxicosis risk especially in view of climatic changes precipitating hot and dry spells associated with increased aflatoxin contamination (Cotty and Jaime-Garcia 2007; Kebede et al. 2012; Smith et al. 2016).

Adverse effects of consumption of aflatoxin contaminated food is linked to a large population of children experiencing poor and stunted growth in Benin (Gong et al. 2004) and in Eastern Kenya (Hoffmann et al. 2015). We hypothesise that the reported stunting effects in Eastern Kenya hot-spot may be attributable to perennial consumption $\mathrm{AFB}_{1}$, -a potent class 1 mutagenic and teratogenic toxin (Birch and Parker 2012; FAO, United Nations 2017). The findings of the current study correspond with the period when the most severe case of aflatoxicosis occurred (between May and June 2004) in Eastern Kenya after the long rain season (Anonymous 2004). This could be explained by the predominant $\mathrm{AFB}_{1}$ observed in the current study and also the same the same period. It is likely that in 2004, $\mathrm{AFB}_{1}$ levels were at a record high and resulted in human fatalities (Probst et al. 2007).

The seasonal variations in levels of toxins is likely the result of variations in the fungal community structure between cropping seasons. That could explain why $\mathrm{AFB}_{1}$ is predominant in the long rain season while there mixed toxins in the short season (Salano et al. 2016). There is also possibility of complex fungal interactions at their specific niche leading to differential toxin production (Huang et al. 2011; Okoth et al. 2018). The possibility of intra - and interspecific interaction between members of a fungi genus remains a confounding phenomenon but deserves attention. Therefore, it remains unclear why $\mathrm{AFB}_{2}$ and $\mathrm{AFG}_{1}$ were present in the second season only whereas the fungi known to produce them were present in isolates from both seasons (Salano et al. 2016).

\section{Conclusions}

The seasonal pattern of aflatoxin contamination of the staple food -maize in Eastern Kenya, presents an opportunity for interventions such as biological control to reduce aflatoxins especially in the long rain season where AFB1 is uniformly produced (Bandyopadhyay et al. 2007; Cotty et al. 2008; Bandyopadhyay et al. 2016). While there is a lack of feasible intervention, the risk of chronic exposure to AFB1 remains high and poorly documented in both cropping seasons. Hence the findings of this study necessitate mitigation measures because $\mathrm{AFB}_{1}-$ is a potent class 1 mutagenic toxin likely to cause liver cancer.

\section{Abbreviations}

$\mathrm{AFB}_{1}$ : Aflatoxin $\mathrm{B}_{1} ; \mathrm{AFB}_{2}$ : Aflatoxin B2; $\mathrm{AFG}_{1}$ : Aflatoxin $\mathrm{G}_{1} ; \mathrm{AFG}_{2}$ : Aflatoxin G2; ELISA: Enzyme-linked immunosorbent assay; FAO: Food and agriculture organization; HPLC: High-performance liquid chromatography; masl: meters above sea level; RH: Relative humidity; TLC: Thin-layer chromatography

\section{Acknowledgements}

The authors express their heartfelt gratitude to the farmers, county government in the greater Eastern Kenya for their co-operation. We appreciate Collins

Odhiambo, Herman Otieno for their tremendous laboratory support. The analysis was carried out at the Mycotoxin Research Laboratory, Biochemistry Department Egerton University.

\section{Funding}

The authors acknowledge funding from the Bill and Melinda Gates Foundation (Grant ID\# OPP1060246) from which reagents to carry out the analysis were purchased. Sampling was carried out with support from the National Commission for Science and Technology Foundation (NACOSTI/RCD/ST\&l 5th Call MSc 085) while Grand Challenges Canada (Grant ID S7 0656-01-10) supported the cost of HPLC Analysis.

\section{Availability of data and materials}

"Data sharing not applicable to this article as no datasets were generated or analysed during the current study."

\section{Authors' contributions}

MAO designed the experiment and undertook data analysis, revised the manuscript critically for important intellectual content and gave final approval of the version to be published. ENS carried out the analysis, drafted the manuscript and revised it critically for important intellectual content and gave final approval of the version to be published. Both authors read and approved the final manuscript.

\section{Ethics approval and consent to participate}

Samples were willingly provided by the participating farmers in Eastern Kenya. Permission was sought to obtain samples from the head of each household.

Consent for publication

All authors read and approved the final manuscript.

\section{Competing interests}

The authors declare that they have no competing interests.

\section{Publisher's Note}

Springer Nature remains neutral with regard to jurisdictional claims in published maps and institutional affiliations.

Received: 3 April 2018 Accepted: 23 August 2018

Published online: 31 August 2018

\section{References}

Anonymous. Outbreak of aflatoxin poisoning - Eastern and Central provinces, Kenya, January-July 2004. MMWR. 2004;53(34):790-3.

Bandyopadhyay R, Kumar M, Leslie JF. Relative severity of aflatoxin contamination of cereal crops in West Africa. Food Addit Contam. 2007;24(10):1109-14.

Bandyopadhyay R, Ortega-Beltran A, Akande A, Mutegi C, Atehnkeng J, Kaptoge $L$, et al. Biological control of aflatoxins in Africa: current status and potential challenges in the face of climate change. WMJ. 2016;9(5):771-89.

Birch GG, Parker KJ. Food and health: science and technology. New York: Springer Science \& Business Media; 2012.

Cotty PJ, Jaime-Garcia R. Influences of climate on aflatoxin producingfungi and aflatoxin contamination. Int J Food Microbiol. 2007;119(1-2):109-15. 
Cotty PJ, Probst C, Jaime-Garcia R. Etiology and management of aflatoxin contamination. In: Leslie JF, Bandyopadhyay R, Visconti A, editors. Mycotoxins: detection methods, management, public health, and agricultural trade. Wallingford: CAB International; 2008. p. 287-99.

Cusumano V, Rossano F, Merendino RA. Immunobiological activities of mold products: functional impairment of human monocytes exposed to aflatoxin B sub (1). Res Microbiol. 1996;147(5):385-91.

Food and Agriculture Organization of the United Nations (FAO) Mycotoxins in grain. 2017. http://www.fao.org/wairdocs/x5008e/x5008e01.htm. Accessed 27 Sept 2017.

Freeman AH, Coe R. Smallholder farmers use of integrated nutrient management strategies: Patterns and possibilities in Machakos District of Eastern Kenya. In: Barrett CB, Place F, Aboud AA, editors. Natural resource management in African agriculture. New York: CABl; 2002. p. 143-54.

Gautam DN, Bhatta R, Bhandary MR. Assessment of aflatoxin B1 level in chilli, maize and groundnut samples from Kathmandu Valley. J Food Sci Tech Nepal. 2008;4:57-60.

Gong Y, Hounsa A, Egal S, Turner PC, Sutcliffe AE, Hall AJ, Cardwell K, Wild CP. Postweaning exposure to aflatoxin results in impaired child growth: a longitudinal study in Benin, West Africa. Env Health Persp. 2004;112(13):1334-8.

Hoffmann V, Jones K, Leroy J. Mitigating aflatoxin exposure to improve child growth in eastern Kenya: study protocol for a randomized controlled trial. Trials. 2015;16:552. https://doi.org/10.1186/s13063-015-1064-8.

Huang C, Jha A, Sweany R, DeRobertis C, Damann KE Jr. Intraspecific aflatoxin inhibition in Aspergillus flavus is thigmoregulated, independent of vegetative compatibility group and is strain dependent. PLoS One. 2011;6(8):e23470. https://doi.org/10.1371/journal.pone.0023470.

Jager AV, Tedesco MP, Souto PCMC, Oliveira CAF. Assessment of aflatoxin intake in São Paulo, Brazil. Food Control. 2013;33(1):87-92.

Jonsyn-Ellis FE. Seasonal variation in exposure frequency and concentration levels of aflatoxins and ochratoxins in urine samples of boys and girls. Mycopathologia. 2001;152(1):35-40.

Juti M. Impact of push-pull technology on incidence and severity of maize ear rots and mycotoxins in Western Kenya. Master of Science Thesis: Egerton University; 2017.

Kebede H, Abbas HK, Fisher DK, Bellaloui N. Relationship between aflatoxin contamination and physiological responses of corn plants under drought and heat stress. Toxins. 2012;4(11):1385-403.

Mehl HL, Cotty PJ. Variation in competitive ability among isolates of Aspergillus flavus from different vegetative compatibility groups during maize infection. Phytopathology. 2010;100(2):150-9. https://doi.org/10.1094/PHYTO-100-2-0150

Milani JM. Ecological conditions affecting mycotoxin production in cereals: a review. Vet Med. 2013;58(8):405-11.

Mugo RMJ, Ininda M, Okoola RE. Inter annual variability of onset and cessation of the long rains in Kenya. J Meteorol Relat Sci. 2016;9:30-47.

Okoth S, De Boevre M, Vidal A, Diana Di Mavungu J, Landschoot S, Kyallo M, Njuguna J, Harvey J, De Saeger S. Genetic and toxigenic variability within aspergillus flavus population isolated from maize in two diverse environments in Kenya. Front Microbiol. 2018;9:57. https://doi.org/10.3389/fmicb.2018.00057.

Probst C, Bandyopadhyay R, Price LE, Cotty PJ. Identification of atoxigenic Aspergillus flavus isolates to reduce aflatoxin contamination of maize in Kenya. Plant Dis. 2011;95(2):212-8.

Probst C, Njapau H, Cotty P. Outbreak of an acute aflatoxicosis in Kenya in 2004: identification of the causal agent. Appl Environ Microbiol. 2007;73(8):2762-4.

Salano EN, Obonyo MA, Toroitich FJ Odhiambo BO, Aman BO. Diversity of putatively toxigenic Aspergillus species in maize and soil samples in an aflatoxicosis hotspot in eastern Kenya. Afr J Microbiol Res. 2016;10(6):172-84.

Smith LE, Stasiewicz M, Hestrin R, Morales L, Mutiga S, Nelson RJ. Examining environmental drivers of spatial variability in aflatoxin accumulation in Kenyan maize: potential utility in risk prediction models. Afr J Food Agric Nutr Dev. 2016:16(3):11086-105.

Torres AM, Barros GG, Palacios SA, Chulze SN, Battilani P. Review on pre-and post-harvest management of peanuts to minimize aflatoxin contamination. Food Res Int. 2014;62:11-9.

Ready to submit your research? Choose BMC and benefit from:

- fast, convenient online submission

- thorough peer review by experienced researchers in your field

- rapid publication on acceptance

- support for research data, including large and complex data types

- gold Open Access which fosters wider collaboration and increased citations

- maximum visibility for your research: over $100 \mathrm{M}$ website views per year

At BMC, research is always in progress.

Learn more biomedcentral.com/submissions 